\title{
Role of Forestry Police in Animal Protection in Alas Purwo National Park Area
}

\author{
Eko Setiawan*, Keppi Sukesi, Kliwon Hidayat and Yayuk Yuliati \\ Agricultural Sciences, Universitas Brawijaya, Indonesia.
}

\begin{abstract}
This research illustrates and explains the role of forestry police in maintaining the sustainability of forest areas so that they are maintained. The method used in this research is a sociological approach with case study design. The type of research used is descriptive qualitative. The results showed that the role of forestry police in guarding the Alas Purwo National Park area, especially endemic animal theft has been followed up. As with the fact that poaching and utilization of wildlife is endemic, for business and pleasure purposes (hobbies and collections) has resulted in thousands of wild animals of various types endangered. This form of violation has been followed up by the forestry police and sanctioned to the perpetrators. To minimize animal theft, cooperation and community participation are needed both technical and non-technical.
\end{abstract}

Keywords: Animal Protection, Alas Purwo National Park, Forestry Police.

\section{INTRODUCTION}

Indonesia is one of the countries with a large tropical forest, and ranked third in the world after Brazil (1). This condition certainly makes Indonesia's forests as oxygen as well as have a source of germplasm that must be maintained sustainability. As stated in Law No. 41 of 1999 on forestry, mentioning protected forests is a forest area that has a basic function as a protection of life buffer system to regulate water system, prevent flooding, control erosion, and maintain soil fertility. In the explanation of article 50 paragraph 2, Forestry Law No. 41 of 1999 , it is stated that forest destruction results in physical changes in forests or bio-forests that cause forests to be disturbed or unable to play a role in their function. Therefore, it is the duty of human beings to always think about preserving the forest, in order to provide a positive kontrbusi for life (2).
Alas Purwo National Park is one of the natural resources that must be preserved because it is intended as a balance of nature and the lungs of the earth. In forest ecosystems there are various biodiversity and non-biological, both flora and fauna. From a variety of biological natural resources there are a variety of animals. Various kinds of animals are found among them are endemic animals of Indonesia, being unique because it has distinctive characteristics. Therefore, there needs to be a protection against the diversity of these animals. It is human duty to always maintain the sustainability of the forest, in order to make a positive contribution to life.

The diversity of animals and their ecosystems is one of the most important parts of natural resources, has a function as an element of environmental formation whose presence can not be replaced.

*Address of Correspondence: Eko Setiawan, Doctoral Program in Agricultural Sciences, Universitas Brawijaya, Indonesia. E-mail- eko.pacerot@gmail.com 
But hunting activities against certain animals cause these animals to become rare and even endangered. Animal hunting has actually started since humans existed on the face of the earth, but animal hunting at that time was only for consumption purposes. In this day and age, hunting animals is not only for consumption purposes, some are taken parts of their bodies to be used as handicrafts and for treatment.

The threat of poaching to wildlife is often greater than the threat from habitat loss (3). Wildlife hunting in Alas Purwo National Park, especially the hunting of protected and rare animals, especially birds, is still ongoing today. One of them is green cucak (Chloropsis sonnerati), has a characteristic with a larger posture and has an unquestionable quality of chirping. This advantage is especially evident in his brave mentality, fighting style and gacor voice. The existence of birds is a sign of environmental change or not, one form of bird utilization as bio-monitoring that has been developed in several developed countries, among others, to identify the level of environmental pollution and pesticides (4). This is of course a very serious threat of extinction to various rare species in Indonesia. The sustainability of wildlife requires the participation of communities around forest areas to maintain their habitats and populations so as not to be endangered by irresponsible people, who have hunted one by one the protected animals. The success of conservation area conservation with this concept depends very much on the success in dealing with the socioeconomic problems of the surrounding communities. Disruption to conservation areas will be reduced if the welfare of the communities around the forest can be met from efforts outside the use of forests. Therefore, solutions are needed to reduce public access to forest areas, because people have lived around the Alas Purwo National Park area long before this area was made into a National Park and its status is still Marga Satwa.

\section{RESEARCH METHODOLOGY}

This research uses the paradigm of constructivism as a philosophical foundation for understanding the realities of society. The paradigm of constructivism is normative, showing its practitioners what to do without the need for long existential or epitemological considerations (5). The method used in this study is a sociological approach with a case study design. Qualitative research emphasizes processes and meanings that are not rigorously tested or measured in terms of quantity or frequency (6). Informants are defined with purposive techniques. Data collection using observations and interviews. This research focuses on extracting data related to the interaction of local communities around the Alas Purwo National Park area, as well as the excavation of information on the causes of declining diversity of wildlife species due to uncontrolled wildlife hunting activities. Thus, the harmonization of communication and interaction can be achieved to the maximum (7). Data analysis using interactive models, including components, data collection, data reduction, data feed, draw conclusions.

\section{RESULT AND DISCUSSIONS BIRD WILDLIFE POACHING}

Birds are easy to find, even some species of birds live around us. Birds are a group of animals capable of living in a variety of environmental conditions. From polar ice poles to deserts, from oceans to mountain peaks, even from wilderness to urban birds are able to live. In general, birds have characteristics, namely: having feathers as a cover of their body, a beakshaped mouth, front limbs in the form of wings, having air pundi-pundi, the end of the digestive system fused with parts of the body for reproduction in the form of cloaca. On the body parts of birds have a unique shape, such as color patterns on feathers that vary and differ by each breed. The shape of the beak and the shape of the legs, are parts of the body that often have a unique shape.

Alas Purwo National Park as a conservation area for nature conservation has a large number of bird species. The wealth of bird species in Alas Purwo National Park, reported as many as 227 species (8). Peacocks, white starlings, part chickens, are typical bird species found in Alas Purwo National Park (9). The types of birds in Alas Purwo National Park that are often caught and used as chirping birds, among others: green cucak (Chloropsis 
sonnerati)(10). Habitats of bird species including green cucak (Chloropsis sonnerati) are in great demand by bird enthusiasts and have a relatively high price (11). The factor of excessive utilization is worried that it can threaten ecological conditions, both to the fauna of birds and their habitat. The presence of birds in an area has important meanings, one of which is as an indicator of the biology of a region (12).

Entering the summer in the Alas Purwo National Park area is believed to start rampant poaching because many species of birds are getting exploitation, both hunting and trading. Because in the summer, the birds gather at one point only at the water source. From there poachers install nets or traps to catch birds or lure wild birds using the sound of birds from cassette tapes. It is different when the rainy season comes because the birds will spread throughout the forest area along with abundant water supplies. Various types of birds have a fairly high economic value, based on morphological potential, sound, behavior. This economic potential leads to high bird hunting so that it can decrease the population. In addition, bird habitats are also decreasing in quality and quantity, due to overexploitation of forests. The problem causes disruption of the sustainability of bird animals which ultimately leads to scarcity.

According to information from polhut informant Samto Hidayat, last summer managed to catch the person involved in the poaching, namely a couple. The wife is tasked with selling hunting birds, while the husband is tasked with finding birds in the middle of the forest. Bird hunts will usually be sold to fences or markets. To trick the officer, the wife pretends to be a vegetable seller. The bird of evil was put into a pipe made of bamboo, then transported using a basket on which placed a pile of various vegetables. The guise of crime can be uncovered because officers have already pocketed information related to the action.

In order to control the activities of poaching animals required a mapping of the hunting system which is a system identification activity through investigation of the components contained in a hunt. Through identification can also be known the intensity of poaching that occurs in an area so that it can be determined the level of insecurity of an area against hunting activities against animals. Categories of poaching by purpose include:

1. Hunting for pleasure, which is hunting done by people who feel physical freshness after hunting activities and consider hunting animals is a form of pleasure.

2. Hunting with non-commercial purposes, namely hunting carried out to meet daily food needs. In general, poaching of these animals is carried out using traditional tools.

3. Hunting with economic purposes, namely hunting carried out with the aim of being traded or traded to certain parties who need it and doing animal hunting as a livelihood.

Based on the identification process, prevention efforts can be made against poaching and animal trafficking activities, even with sanctions that will be given in the event of violations. Arrangements regarding hunting of protected animals in Indonesia have been formulated in Law No. 5 of 1990 on the Conservation of Biological Natural Resources and Their Ecosystems. The existence of a prohibition governing the hunting and trafficking of protected animals becomes the basis for law enforcement against the implementation of its duties in handling illegal trafficking cases. But law enforcement cannot work alone because law enforcement needs help from conservation agencies to treat government-seized animals in illegal trafficking cases.

\section{THE ROLE OF FOREST POLICE ON THE SUSTAINABILITY OF ALAS PURWO NATIONAL PARK}

Forest police officers are functionalist officials of the Ministry of Environment and Forestry (KLHK) given duties and responsibilities and rights in full by the central authority to carry out forest protection. In the implementation of its duties, special police skills and skills are needed to overcome the perpetrators of crimes and forestry crimes. The protection and supervision of Alas Purwo National Park is an effort to minimize forest encroachment, theft of 
biological natural resources. This is a problem that is commonly faced by almost all national park management areas. Forest police are the spearhead of the creation of protection and preservation of national park areas. Forest police are one of the officers who have legal authority in regulating social life. Forest police carry out special police duties and functions in the field of forestry, so as to use its authority to carry out preventive measures of forest security. The performance of forest police is strongly influenced by individual factors, psychological factors and the environment in which they work (13). Forest protection is an effort to protect and protect forests from various disturbances that can disturb and damage natural resources (14).

Forestry police is the name of a functional position of Civil Servants in the environment of employees of central and local forest agencies. Forestry Police is a specific official within the scope of central or regional forestry agencies in accordance with the nature of its work carrying out forest protection efforts. Constitutionally granted special police authority in the field of forestry and conservation of biological natural resources and their ecosystems. As the name implies, this forestry police has the main task of preparing, implementing, monitoring, and evaluating and reporting forest protection and security activities as well as monitoring the distribution of forest products. Due to the nature of its work in the efforts to safeguard and protect forests, certain officials are given special authority in the field of forestry and conservation of biological natural resources and their ecosystems.

Security disturbances in the Alas Purwo National Park area can be said to be relatively safe when compared to other conservation areas. The majority of security disturbances occurred in the Alas Purwo National Park area, dominated by timber theft, retrieval and poaching of animals. The challenges of managing Alas Purwo National Park in the future will certainly get tougher, because this national park area directly borders the lands of communities with low socioeconomic conditions. Therefore, an active role is expected in maintaining the security of Alas Purwo National Park from any disturbances from the community. One of them is through socialization conducted by the Forest Police to pendarung, spritual actors, by sitting together and given material on how to maintain forest sustainability, responsible for maintaining forest sustainability for the common good, and also not forgetting to be conveyed about the rules, laws, rights if located in the Alas Purwo National Park area.

Socialization as a form of anticipation of everything that is considered important for Forest Police officers, in maintaining forest conservation from all forms of potential damage caused by communities active in the area. In the event of an unintended event, it will have an impact on the forest ecosystem, thus harming all parties. In addition to socialization, patrols are also carried out to areas prone to violations while recording data and recording along the way, including former violation lanes, the excellent potential of both biodiversity and tourist attractions. Security activities in Alas Purwo National Park involving the community is a form of local wisdom. The practice of community involvement in regional security activities has been carried out since long time ago. The nature of security also includes problems in the form of conservation. The community knows the potential threats and disruptions to the utilization of natural resources, and is the spearhead in maintaining the sustainability of natural resources therefore, the participation of local communities needs to be raised and encouraged to be more active.

\section{CONCLUSION}

Wildlife hunting in Alas Purwo National Park, especially the hunting of protected and rare animals, especially birds, is still ongoing today. One of them is green cucak (Chloropsis sonnerati), has a greater posture and has an unquestionable chirping quality. Types of wildlife hunting by purpose, consists of:

1. Hunting for pleasure, which is hunting done by people who feel physical freshness after hunting activities and consider hunting animals is a pleasure.

2. Hunting with non-commercial purposes, namely hunting carried out to meet daily food needs. In general, poaching of these animals is carried out using traditional tools. 
3. Hunting with economic purposes, namely hunting carried out with the aim of being traded or traded to certain parties who need it or doing animal hunting as a livelihood.

The nature of the forestry police's work in the efforts to safeguard and protect forests, certain officials are given special police authority in the field of forestry and conservation of biological natural resources and their ecosystems. One of them is by means of socialization as a form of anticipation of everything that is considered important for certain circles, including forest police officers, in maintaining forest conservation from all forms of potential damage caused by communities active in the area.

\section{CONFLICT OF INTEREST}

There is no conflict of interest in this present research paper. This research work is not a part of any other studies and it is our original work.

\section{REFERENCES}

1. Supriadi. 2011. Hukum Kehutanan \& Hukum Perkebunan di Indonesia. Jakarta: Sinar Grafika.

2. Iskandar, Mustoha. 2015. Dai Agent of Change. Jakarta: Duta Rimba.

3. Benneett EL, AJ Nyaoi. Hornbills Buceros spp and Culture in Northern Borneo: Can they continue to coexist? Biological Conservation. 1997; 82: 41-46.
4. Furness RW and JJD Greewood (ed). 1993. Bird as Monitors of Enviromental Change. Chapman \& Hall. London.

5. Mulyana Deddy. 2003. Metodologi Penelitian Kualitatif. Bandung: PT Remaja Rosdakarya.

6. Denzin NK and YS Lincoln (eds). 2000. Handbook of Qualitatif Research (Second Edition), Thousand Oaks, London, New Delhi: Sage Publication.

7. Neuman William Lawrence. 2003. Social Research Methods: Qualitative and quantitative Approaches. Pearson Education.

8. Grantham, MI. Bird of Alas Purwo National Park, East Java. Kukila. 2000; 11: 97-121.

9. Hoogerwerf A. 1974. Report on Visit to Wild Life Reserves in East Java, Indonesia.

10. Balen SVan. The Distribution and Status of Green Peafowl Pavo Muticus in Java. Biological Conservation. 1995; 71: 289-297.

11. Hernowo JB. Population Study of Javan Green Peafowl (Pavo muticus muticus Linneaus 1758) with Three Different Methods in Baluran National Park, East Java, Indonesia. Media Konservasi. 1997; 5 (2): 61-66.

12. Hernowo JB dan Indrajaya A. 1999. Kajian Penyebaran, Populasi dan Habitat Jalak Putih di Taman Nasional Alas Purwo, Jawa Timur. Makalah dipresentasikan pada loka karya "Rencana Pemulihan Gelatik Jawa dan Jalak Putih" di Gedung Widyasatwaloka, Puslitbang Biologi LIPI. Cibinong, 12 Desember 1999.

13. Gibson JL, Ivancevich JM, Donelly JH, Konopaske R. 2012. Organizations Behavior, Structure, Processes. New York (USA).

14. Purwanto, H. 2010. Upaya Rehalibilitasi Hutan dan Lahan Mengurangi Polusi dan Pencemaran. Pelalawan Riau: BLH. 